\title{
Inhibition of the mycelial growth and germination of Stromatinia cepivora by plant extracts and essential oils
}

\section{Inibição do crescimento micelial e germinação de Stromatinia cepivora por extratos vegetais e óleos essenciais}

\section{Cícero Augusto Guimarães FUGA ${ }^{1}$; Everaldo Antônio LOPES ${ }^{2}$; Bruno Sérgio VIEIRA ${ }^{3}$; Márcio Santos SOARES ${ }^{4}$; Regina Victória de Barros FERNANDES ${ }^{5}$}

\begin{abstract}
1 Programa de Pós-Graduação em Produção Vegetal, Instituto de Ciências Agrárias, Universidade Federal de Viçosa, Campus de Rio Paranaíba. Rodovia MG 230, km 07, Caixa Postal 22, 38810-000, Rio Paranaíba - MG. E-mail: cicero.fuga@nooabrasil.com.br

${ }^{2}$ Autor para correspondência. Programa de Pós-Graduação em Produção Vegetal, Instituto de Ciências Agrárias, Universidade Federal de Viçosa, Campus de Rio Paranaíba. Rodovia MG 230, km 07, Caixa Postal 22, 38810000, Rio Paranaíba - MG. E-mail: everaldolopes@ufv.br

3 Universidade Federal de Uberlândia, Campus de Monte Carmelo, Rodovia LMG 746, km 01, Bloco 1 AMC, 38500-000, Monte Carmelo - MG. E-mail: brunovieira@iciag.ufu.br

${ }^{4}$ Instituto de Ciências Exatas, Universidade Federal de Viçosa, Campus de Rio Paranaíba. Rodovia MG 230, km 07, Caixa Postal 22, 38810-000, Rio Paranaíba - MG. E-mail: marciosoares@ufv.br

${ }^{5}$ Universidade Federal de Lavras, Departamento de Química, Campus Universitário, Caixa Postal 3037, 37200000, Lavras - MG. E-mail: regiane.botrel@dqi.ufla.br
\end{abstract}

Recebido em: 23-02-2018; Aceito em: 03-05-2018

\begin{abstract}
Stromatinia cepivora is one of the major pathogens of Allium species worldwide. Assuming that substances produced by plants may be used in the management of this pathogen, the effect of plant extracts and essential oils on the mycelial growth and germination of $S$. cepivora was assessed in this study. The fungus was grown on PDA medium with aqueous and ethanolic extracts $(20 \%, \mathrm{~m}: \mathrm{v})$ of mentrasto, rue, ginger, false saffron, garlic and citronella at the concentrations of 1 or $10 \mathrm{~mL} \mathrm{~L}^{-1}$ and the essential oils of citronella, rosemary, neem and Corymbia citriodora at $100,200,400,800$ or $1,200 \mu \mathrm{L} \mathrm{L}^{-1}$. None of the plant extracts reduced the germination of the sclerotia. All aqueous extracts at $10,000 \mu \mathrm{L} \mathrm{L}^{-1}$ reduced the growth of the fungus from $28.0 \%$ to $53.5 \%$. At the $1,000 \mu \mathrm{L} \mathrm{L}-1$, the ethanolic extracts of ginger, citronella, rue and false saffron reduced the mycelial growth of the pathogen up to $45.1 \%$, especially the extract of ginger. The essential oils of all the plants suppressed the mycelial growth of $S$. cepivora at 800 and $1,200 \mu \mathrm{L} \mathrm{L}^{-1}$, especially the citronella and rosemary oils at $1,200 \mu \mathrm{L} \mathrm{L}^{-1}$, which caused $100 \%$ of inhibition. $5 \%$ of sclerotia germinated in PDA containing the oils at $1,200 \mu \mathrm{L} \mathrm{L}^{-1}$, regardless the plants. The extracts of mentrasto, rue, ginger, false saffron and citronella and especially the essential oils of citronella, rosemary, neem and $C$. citriodora at $1,200 \mu \mathrm{L} \mathrm{L}-1$ have substances that inhibit the growth of $S$.
\end{abstract} cepivora.

Additional keywords: Allium spp.; alternative control; white rot.

\section{Resumo}

Stromatinia cepivora é um dos principais patógenos de espécies de Allium em todo o mundo. Partindo do pressuposto de que substâncias produzidas por plantas podem ser usadas no manejo desse patógeno, o efeito de extratos vegetais e de óleos essenciais sobre o crescimento micelial e a germinação de $S$. cepivora foi avaliado neste estudo. O fungo foi cultivado em BDA com extratos aquosos e etanólicos (20\%, m: v) de mentrasto, arruda, gengibre, falso-açafrão, alho e citronela, nas concentrações de 1 ou $10 \mathrm{~mL} \mathrm{~L}^{-1}$ e os óleos essenciais de citronela, alecrim, nim e eucalipto citriodora, a 100; 200; $400 ; 800$ ou $1.200 \mu \mathrm{L} \mathrm{L}^{-1}$. Nenhum dos extratos de plantas reduziu a germinação dos escleródios. Todos os extratos aquosos a $10.000 \mu \mathrm{L} \mathrm{L}^{-1}$ reduziram o crescimento do fungo, variando de $28,0 \%$ a $53,5 \%$. Na concentração de $10.000 \mu \mathrm{L} \mathrm{L}^{-1}$, os extratos etanólico de gengibre, citronela, arruda e falso-açafrão reduziram o crescimento micelial do patógeno até $45,1 \%$, especialmente o extrato de gengibre. Os óleos essenciais de todas as plantas suprimiram o crescimento micelial de S. cepivora a 800 e

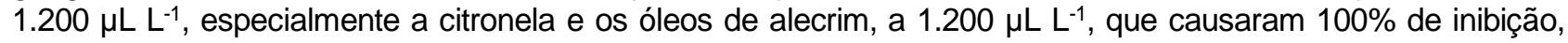
$5 \%$ dos escleródios germinados em BDA contendo os óleos na concentração de $1.200 \mu \mathrm{L} \mathrm{L}^{-1}$, independentemente da planta. Os extratos de mentrasto, arruda, gengibre, açafrão e falsa-citronela e, especialmente, os óleos essenciais de citronela, alecrim, nim e eucalipto citriodora, em $1200 \mu \mathrm{L} \mathrm{L}^{-1}$, têm substâncias que inibem o crescimento de $S$. cepivora.

Palavras-chave adicionais: Allium spp.; controle alternativo; podridão-branca. 


\section{Introduction}

White rot caused by the fungus Stromatinia cepivora (Berk.) Whetzel (synonym Sclerotium cepivorum Berk.), is one of the principal diseases of garlic and onion worldwide, especially in regions where cultivation occurs during the coldest times of the year (Fuga et al., 2012). In infested areas, losses caused by this disease may reach $100 \%$ (Pinto et al., 2000). The sclerotia formed by S. cepivora can guarantee its survival in the field for up to 20 years (Coley-Smith et al., 1990). Therefore, growers must avoid introducing this pathogen into non-infested areas, since it is difficult to eradicate the fungus (Brewster, 2008).

Different control strategies have been used to manage white rot. Fungicides may be applied during pre-planting by fumigating the soil with metam sodium, in combination with clove treatment and post-planting spraying of products based on tebuconazole, iprodione, procymidone, vinclozolin and boscalid (Zewide et al., 2007; Villalta et al., 2012). However, fungicides efficacy may be poor under high pressure of sclerotia density in soil (Zewide et al., 2007). Other strategies for managing white rot are soil solarization, biofumigation, and the application of germination stimulants of sclerotia germination and biological control agents (Davis et al., 2007; Stewart \& McLean, 2007; Villalta et al., 2012). However, the search for additional methods of white rot must continue due to the difficulty of controlling the pathogen.

Prospecting for fungicidal substances produced by plants during their secondary metabolism may result in additional options for integrated management of $S$. cepivora. Various species of medicinal, aromatic and culinary plants have substances toxic to several plant pathogens (Park et al., 2007; Tabanca et al., 2007; Pinto et al., 2010; Combrinck et al., 2011). However, little is known about which plants have compounds inhibitory to $S$. cepivora, except for Crotalaria paulina Schrank, Corymbia citriodora Hill \& Johnson (Pinto et al., 1998), Syzygium aromaticum (L.) Merr \& Perry and Pimenta dioica (L.) Merr (Montes-Belmont \& Prados-Ligero, 2006). It is likely that fungitoxic substances found in other plant species may be useful for S. cepivora. Based on this perspective, it was assessed in this work the effect of the aqueous and ethanolic extracts of mentrasto (Ageratum conyzoides L.), rue (Ruta graveolens L.), ginger [Zingiber officinale (Willd) Roscoe], false saffron (Curcuma longa L.), garlic (Allium sativum L.) and citronella (Cymbopogon winterianus Jowitt ex Bor ), and the essential oils of citronella, rosemary (Rosmarinus officinalis L.), neem (Azadirachta indica A. Juss) and eucalyptus citriodora (C. citriodora) on the mycelial growth and germination of $S$. cepivora.

\section{Material and methods}

\section{Pathogen Isolation}

The $S$. cepivora isolate used in this study was obtained from sclerotia formed on the surface of garlic bulbs, collected from crops from Rio Paranaíba, Minas Gerais State, Brazil. In the laboratory, the sclerotia were disinfected in $50 \%$ alcohol and $0.5 \%$ sodium hypochlorite for 30 and 60 seconds. The sclerotia were then rinsed in sterile distilled water and transferred to Petri dishes containing potato dextrose agar (PDA) medium. The Petri dishes were kept at $20{ }^{\circ} \mathrm{C}$. After the germination and fungal growth, a $5 \mathrm{~mm}$ mycelium disc was removed from the edge of the colony and transferred to the Petri dish, with the pathogen incubated in $\mathrm{BOD}$ at $20^{\circ} \mathrm{C}$ in the dark for 10 days.

\section{Preparation of Extracts}

Leaves of citronella, rue and mentrasto, rhizomes of false saffron and ginger and bulbs of garlic were washed in running tap water and surface-disinfected using sodium hypochlorite at $0.5 \%$ for $10 \mathrm{~min}$. The plant materials were grounded in a blender with autoclaved $(120 \stackrel{\circ}{\circ}$ for $1 \mathrm{~h}$ ) distilled water or ethanol at $96{ }^{\circ} \mathrm{GL}$ for $1 \mathrm{~min}$. The extracts were prepared using $200 \mathrm{~g}$ of plant per $\mathrm{L}$ of solvent. The aqueous extracts were placed in water-bath at $60 \stackrel{\circ}{\circ}$ for $1 \mathrm{~h}$ to improve the extraction efficiency. Both the extracts were separated from the residual solid material by filtration, using filter paper with $3 \mu \mathrm{m}$ pores, and then a system with a $0.2 \mu \mathrm{m}$ nitrocellulose membrane (Millipore ${ }^{\circledR}$ ). The extracts were stored in capped tubes, wrapped in aluminum foil and kept in a refrigerator at $4{ }^{\circ} \mathrm{C}$.

\section{Effect of plant extracts on the inhibition of the mycelial growth and germination of $S$. cepivora}

The plant extracts were added to the PDA ( $45^{\circ} \mathrm{C}$ ) at concentrations of 1 or $10 \mathrm{~mL} \mathrm{~L}^{-1}$, along with adjuvant Tween 80 at $0.05 \%$ and the antibiotic streptomycin sulfate at a concentration of $500 \mathrm{mg} \mathrm{L}^{-1}$. The culture media with and without plants extracts were distributed in Petri dishes $(9 \mathrm{~cm}$ in diameter). Mycelium discs $(6 \mathrm{~mm}$ in diameter) were removed from the edges of the seven-day-old $S$. cepivora colonies and placed in the center of Petri dishes with PDA. The plates were kept in $B O D$ in the dark at $20{ }^{\circ} \mathrm{C}$ for 10 days. The experiment was finalized when the fungal colonies reached the entire surface of the medium on plates containing only PDA (control). The diameter of the colonies was measured with a digital caliper.

To evaluate the effect of the extracts on sclerotia germination, six sclerotia from 12-day-old pure colonies were placed at equidistant points on the surface of PDA amended or not with plant extracts kept on Petri dishes ( $9 \mathrm{~cm}$ in diameter). The plates were kept at $20{ }^{\circ} \mathrm{C}$ in the dark for seven days. The number of germinated sclerotia was evaluated with the help of a stereoscopic microscope at 40X.

A completely randomized design was used in the experiments with a $7 \times 2 \times 2$ factorial scheme (six plant species or control $\times$ concentrations of 1 or $10 \mathrm{~mL} \mathrm{~L}^{-1} \times$ extracts preparation using water or ethanol) and five replicates each. PDA media amended with distilled water or ethanol, Tween 80 and streptomycin sulfate was used as control. Each Petri dish was considered an experimental unit. The experiments were conducted twice. The data were 
subjected to the Shapiro-Wilks and Levene tests for normality and homogeneity of variances. Due to the homogeneity of variances between the experiments evaluated by means of the Cochran test (Gomez \& Gomez, 1994), the data were grouped and analyzed together. Analysis of variance (ANOVA, F Test, $P=0.05)$ was performed and the treatments were compared by means of the Tukey test $(P=0.05)$, with the use of the statistical package $R$ version 3.1.1 (R Development Core Team, 2014).

\section{Effect of essential oils on the inhibition of the mycelial growth and germination of Stromatinia cepivora}

Commercial essential oils of citronella, rosemary, neem and eucalyptus citriodora (100\% pure; Lazlo Aromaterapia, Belo Horizonte, Brazil) were filtered with a $0.2 \mu \mathrm{m}$ nitrocellulose membrane and added to PDA at $100,200,400,800$ or $1,200 \mu \mathrm{L} \mathrm{L}^{-1}$, along with Tween 80 at $0.05 \%$ and streptomycin sulfate at $500 \mathrm{mg} \mathrm{L}^{-1}$. The experiment was carried out and evaluated similarly to the extracts experiments, except for the duration of 15 days and the germination of the sclerotia was evaluated using agar-water instead of PDA.

A completely randomized design was used in a $4 \times 5+1$ factorial scheme (plant oils $\times$ concentrations + control), with five replicates. PDA media amended with distilled water or ethanol, Tween 80 and streptomycin sulfate was used as control. Each Petri dish was considered an experimental unit. The experiments were conducted twice. Data were also grouped from both experiments, due to the homogeneity of the variances, followed by analysis of variance (F Test, $P=0.05$ ) and the qualitative treatments (types of plant oils) were compared by means of the Tukey test $(P=0.05)$. The quantitative factors (essential oil concentrations) were evaluated after adjusting the regression equations $(P=0.05)$. The oils and the respective concentrations were compared with the control by Dunnett's test $(P=0.05)$. All analyses were done using the statistical package $R$ version 3.1.1 (R Development Core Team, 2014).

\section{Results}

The mycelial growth of $S$. cepivora was influenced by the interactions among the plant species, concentrations and extractors (Table 1). In general, none extract reduced the mycelial growth of the fungus by more than $54 \%$. All sclerotia germinated after seven days of incubation, regardless the plant species, extractor and concentration (data not shown).

Analyzing the ethanolic extracts at the concentration of $10,000 \mu L^{-1}$, the rue extract caused the greatest inhibition of mycelial growth of $S$. cepivora $(39.1 \%)$, when compared to the remaining extracts and the control. The extracts of mentrasto and false saffron caused inhibition of 20.8 and $21.1 \%$ (Table 1). All aqueous extracts at $10,000 \mu \mathrm{L} \mathrm{L}^{-1}$ limited the growth of the fungus, from $28.0 \%$ to $53.5 \%$. The extracts of mentrasto and citronella inhibited the diameter of the fungal colony by more than $50 \%$. At the $10,000 \mu \mathrm{L} \mathrm{L}^{-1}$, water was more efficient extractor of inhibitory substances than ethanol, particularly with mentrasto, garlic, citronella and ginger.

At the $1,000 \mu \mathrm{L} \mathrm{L}^{-1}$ concentration, the ethanolic extracts of ginger, citronella, rue and false saffron reduced the mycelial growth of the pathogen, especially the extract of ginger, which limited the diameter of the colony by $45.1 \%$ in relation to the control. No aqueous extract at the concentration of $1,000 \mu \mathrm{L} \mathrm{L}^{-1}$ had antifungal effects above $21 \%$ and only the extracts of rue and false saffron differed from the control (Table 1). At this concentration, the ethanol was more efficient at extracting the inhibitory substances of $S$. cepivora from citronella and ginger.

Table 1 - Inhibition of mycelial growth of Stromatinia cepivora after 15 days of cultivation at $20{ }^{\circ} \mathrm{C}$ in potato dextrose agar culture (PDA) medium amended with aqueous and ethanolic extracts from six plant species at the concentrations of 1,000 and $10,000 \mu \mathrm{L} \mathrm{L}^{-1}$.

\begin{tabular}{lcccc}
\hline \multirow{2}{*}{ Plant } & \multicolumn{5}{c}{ Diameter of the colony $(\mathrm{cm})$} \\
\cline { 2 - 5 } & $10,000 \times$ Ethanol & $10,000 \times$ Water & $1,000 \times$ Ethanol & $1,000 \times$ Water \\
\hline Mentrasto & $7.12 \mathrm{Ab}^{*}$ & $4.18 \mathrm{Bc}$ & $7.50 \mathrm{Aabc}$ & $7.96 \mathrm{Aab}$ \\
Rue & $5.48 \mathrm{Bc}$ & $6.30 \mathrm{ABb}$ & $7.10 \mathrm{Ac}$ & $7.16 \mathrm{Ab}$ \\
False saffron & $7.10 \mathrm{Ab}$ & $6.40 \mathrm{Ab}$ & $6.18 \mathrm{Acd}$ & $7.26 \mathrm{Ab}$ \\
Garlic & $7.58 \mathrm{Aab}$ & $6.06 \mathrm{Bb}$ & $8.70 \mathrm{Aab}$ & $7.42 \mathrm{ABab}$ \\
Citronella & $9.00 \mathrm{Aa}$ & $4.32 \mathrm{Cc}$ & $7.14 \mathrm{Bbc}$ & $9.00 \mathrm{Aa}$ \\
Ginger & $8.78 \mathrm{Aa}$ & $6.48 \mathrm{Bb}$ & $4.94 \mathrm{Cd}$ & $9.00 \mathrm{Aa}$ \\
Control & $9.00 \mathrm{Aa}$ & $9.00 \mathrm{Aa}$ & $9.00 \mathrm{Aa}$ & $9.00 \mathrm{Aa}$ \\
\hline
\end{tabular}

*Means followed by uppercase letters on the line and lowercase letters in the column are not different by the Tukey's test $(P>0.05)$.

There was interaction between the essential oils and concentrations on the mycelial growth of $S$. cepivora. The fungus growth was not reduced by none of the essential oils at 100 and $200 \mu \mathrm{L} \mathrm{L}^{-1}$, similarly to that observed for the citronella and rosemary oils at $400 \mu \mathrm{L} \mathrm{L}^{-1}$ (Table 2). Neem and 
eucalyptus oils at $400 \mu \mathrm{L} \mathrm{L}^{-1}$ inhibited fungal growth by $22 \%$ and $33 \%$, respectively. The essential oils of all the plants reduced the diameter of the pathogen colony at the concentrations of 800 and $1,200 \mu \mathrm{L} \mathrm{L}^{-1}$, especially the citronella and rosemary oils at $1,200 \mu \mathrm{L} \mathrm{L}^{-1}$, which caused $100 \%$ of inhibition.

The effect of the concentrations of each essential oil on the inhibition of the mycelial growth of Stromatinia cepivora was adjusted to exponential models $\left(R^{2}>0.97\right)$ for the citronella and rosemary oils and linear models $\left(R^{2}>0.96\right)$ for neem and eucalyptus oils (Figure 1). The critical points for the citronella and rosemary oils were 256.6 $\mu \mathrm{L} \mathrm{L}^{-1}$ and $263.1 \mu \mathrm{L} \mathrm{L}^{-1}$; whereas the increase in doses of neem and eucalyptus oils limited proportionally the mycelial growth of the pathogen. At the $1,200 \mu \mathrm{L} \mathrm{L}^{-1}$ concentration, the citronella and rosemary oils totally inhibited the mycelial growth of $S$. cepivora, while the neem and eucalyptus oils reduced the growth of the fungus by $77 \%$ and $83 \%$, respectively.

Table 2 - Inhibition of mycelial growth of Stromatinia cepivora after 15 days of cultivation at $20^{\circ} \mathrm{C}$ in potato dextrose agar culture (PDA) medium amended with essential oils from four plant species at the concentrations of $100,200,400,800$, and $1,200 \mu L^{-1}$.

\begin{tabular}{lccccc}
\hline & \multicolumn{5}{c}{ Diameter of the colony $(\mathrm{cm})$} \\
\cline { 2 - 6 } Essential oil & 100 & 200 & 400 & 800 & 1,200 \\
\cline { 2 - 6 } & $9.00 \mathrm{a}$ & $9.00 \mathrm{a}$ & $9.00 \mathrm{~b}$ & $6.03 \mathrm{a}^{*}$ & $0.60 \mathrm{a}^{*}$ \\
\cline { 2 - 6 } Citronella & $9.00 \mathrm{a}$ & $9.00 \mathrm{a}$ & $9.00 \mathrm{~b}$ & $7.02 \mathrm{~b}^{*}$ & $0.60 \mathrm{a}^{*}$ \\
Rosemary & $9.00 \mathrm{a}$ & $9.00 \mathrm{a}$ & $7.02 \mathrm{a}^{*}$ & $5.49 \mathrm{a}^{*}$ & $2.07 \mathrm{~b}^{*}$ \\
Neem & $9.00 \mathrm{a}$ & $9.00 \mathrm{a}$ & $6.03 \mathrm{a}^{*}$ & $6.03 \mathrm{a}^{*}$ & $1.53 \mathrm{~b}^{*}$ \\
Eucaliptus citriodora & 9.00 & 9.00 & 9.00 & 9.00 & 9.00 \\
\hline Control & 9.00 &
\end{tabular}

Means followed by lowercase letters in the column are different by the Tukey test $(\mathrm{P}<0.05)$. ${ }^{*}$ Means are different by the control by the Dunnett's test $(P<0.05)$.

All the sclerotia germinated in the control and the Petri dishes containing PDA amended with essential oils of the four plants at concentrations of $100,200,400$ and $800 \mathrm{LL} \mathrm{L}^{-1}$; while only $5 \%$ of sclerotia, on average, germinated in PDA containing the oils at a $1,200 \mu \mathrm{L} \mathrm{L}^{-1}$ concentration, regardless the plant species (data not shown).

\section{Discussion}

The extracts of mentrasto, rue, ginger, false saffron and citronella and especially the essential oils of citronella, rosemary, neem and eucalyptus citriodora have substances that inhibit the growth of $S$. cepivora. Some fungitoxic substances were already identified in mentrasto (Vieira et al., 2012; Esper et al., 2014), rue (Domingues et al., 2009; Azizi \& Karouei, 2012), ginger (Sharma \& Tiwari, 2013), false saffron (Ferreira et al., 2013; Parveen et al., 2013), citronella (Simic et al., 2008), rosemary (Ozcan \& Chalchat, 2008), neem (Coventry \& Allan, 2001) and eucalyptus citriodora (Aguiar et al., 2014). It is likely that fungicidal substances of wide spectrum present in the extracts and essential oils of these plants are involved in the inhibition of $S$. cepivora, such as precoceno in mentrasto (Vieira et al., 2012), citronellal in citronella and eucalyptus citriodora (Simic et al., 2008; Tomazi et al., 2014), 1.8-cineole (eucalyptol) in ginger and rosemary (Ozcan \& Chalchat, 2008; Sharma \& Tiwari, 2013) and azadirachtin in neem (Coventry \& Allan, 2001).

In addition to the difference in chemical com- position among plant species, the effect of the extracts on the pathogen inhibition also depends on the efficiency of the extract and the quantity of bioactive substances in the plants. The extractor and plant material concentration used in the experiments may therefore influence the results. At high concentrations, such as $10,000 \mu \mathrm{L} \mathrm{L} \mathrm{L}^{-1}$, the efficiency of the water in extracting inhibitory compounds from the mycelial growth of $S$. cepivora was similar or greater than the ethanol (Table 1). However, ethanol was more efficient when the concentration of the plant material was lower $\left(1,000 \mu \mathrm{L} \mathrm{L}^{-1}\right)$. The difference in the fungus inhibition by using distinct solvents in the preparation of the extracts was also reported by Pinto et al. (1998). In their work, the acetone-water extract of $C$. citriodora completely inhibited the germination of the sclerotia of $S$. cepivora when incorporated into the PDA culture medium at the $1,000 \mu \mathrm{LL}^{-1}$ concentration. On the other hand, the aqueous extract of leaves from the same plant and at the same concentration had no effect on the sclerotia germination (Pinto et al., 1998). This difference may occur due to the nature of the compounds extracted by the solvents (Martins et al., 2013). In the present work, both the water and ethanol extracted polar compounds, but the high solubility of the water may result in extracts with many impurities, e.g. organic acids, sugars and soluble proteins (Vizzotto \& Pereira, 2011). Therefore, the high concentration of these impurities may interfere in the action of the fungitoxic substances, limiting the efficiency of aqueous extracts with lower quantities of plant material. 

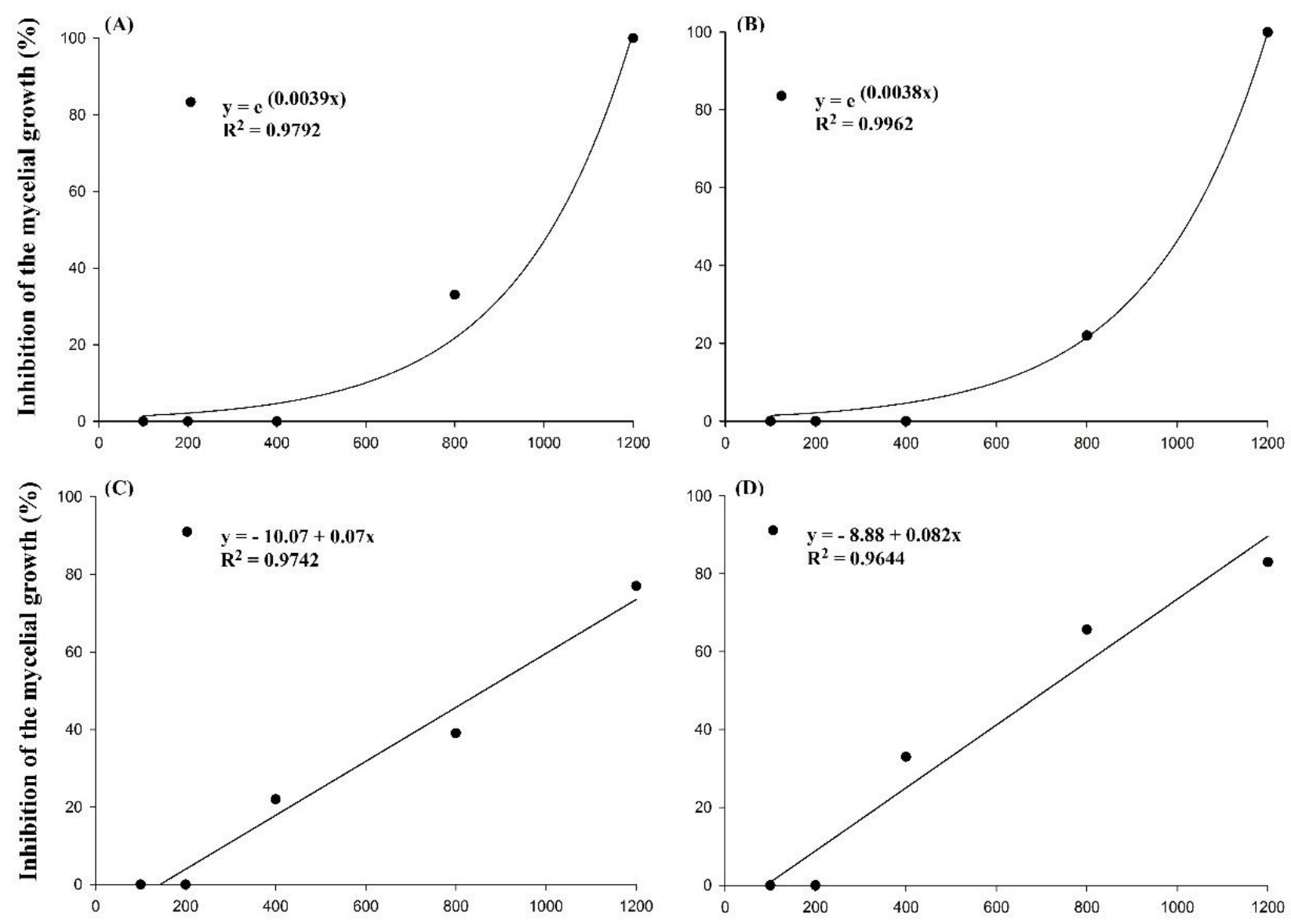

Concentrations of the essential oil $\left(\mu L . L^{-1}\right)$

Figure 1 - Inhibition of mycelial growth of Stromatinia cepivora after 15 days of cultivation at $20^{\circ} \mathrm{C}$ in potato dextrose agar culture (PDA) medium amended with essential oils of citronella (A), rosemary (B), neem (C), and eucalyptus citriodora (D) at concentrations of $100,200,400,800$, and $1,200 \mu \mathrm{L} \mathrm{L}^{-1}$.

The sensitivity of the fungus to plant extracts and essential oils also depends on the type of pathogen propagule, similar to that observed for chemical fungicides. In general, the sensitivity of S. cepivora to the chemical compounds and the action of natural enemies is higher when the hyphae are emitted from the sclerotia (Fuga et al., 2012). It is likely that the extracts of mentrasto, rue, ginger, false saffron and citronella had direct effects on the hyphae expansion velocity but did not interfere with the sclerotia germination process, since only the mycelial growth was inhibited in the experiments with extracts. Sclerotia germination was reduced only the higher concentration $\left(1,200 \mu \mathrm{L} \mathrm{L}^{-1}\right)$ of citronella, rosemary, neem and eucalyptus citriodora essential oils, while mycelial growth was reduced at lower concentrations.

Sclerotia formed by $S$. cepivora are small, melanized and composed of moderately spaced hyphae with the spaces between filled with polysaccharide and protein gels (Fuga et al., 2012). This structural arrangement makes the fungus resistant to many adverse events, including the inhibitory action of some substances. Nonetheless, it was demonstrated in this work that essential oils of citronella, rosemary, neem and eucalyptus citriodora inhibit the germination of $S$. cepivora sclerotia at $1,200 \mu \mathrm{L} \mathrm{L}^{-1}$. The essential oil of these plants is toxic to other phytopathogenic fungi, such as F. oxysporum, Bipolaris sorokiniana, Botrytis cinerea, Cercospora coffeicola, Pyricularia grisea and Rhizoctonia solani (Salgado et al., 2003; Triana \& González, 2009; Soylu et al., 2010; Pereira et al., 2011). The components that determine the biological activity of essential oils are principally the terpenoids and the phenylpropanoides (Bakkali et al., 2008). Therefore, the terpenoids citronellal, eucalyptol and azadirachtin may be the active compounds of citronella, rosemary, neem and eucalyptus citriodora oils. The most likely action mechanism of the essential oils is related to damage to pathogen cell membranes, affecting the structure of its different layers of polysaccharides, fatty acids and phospholipids (Bakkali et al., 2008).

\section{Conclusions}

The extracts of mentrasto, rue, ginger, false saffron and citronella and especially the essential oils of citronella, rosemary, neem and eucalyptus citriodora at $1,200 \mu \mathrm{L} \mathrm{L}^{-1}$ have substances that inhibit the growth of Stromatinia cepivora. 


\section{Acknowledgements}

The authors acknowledge funding received from CNPq, CAPES, and FAPEMIG.

\section{References}

Aguiar RWS, Ootani MA, Ascensio SD, Ferreira TPS, Santos MM, Santos GR (2014) Fumigant antifungal activity of Corymbia citriodora and Cymbopogon nardus essential oils and citronellal against three fungal species. The Scientific World Journal Article ID 492138:8 pages.

Azizi IG, Karouei SMH (2012) Effect of aquatic, methanolic and ethanolic extracts of Ruta graveolens on some mycotoxigenic. American-Eurasian Journal of Agricultural \& Environmental Sciences 12:729-732.

Bakkali F, Averbeck S, Averbeck D, Idaomar M (2008) Biological effects of essential oils. Food and Chemical Toxicology 46:446-475.

Brewster JL (2008) Onions and other vegetable Alliums. CABI Publishing, Wallingford, UK. 454p.

Coley-Smith JR, Mitchell CM, Ansford CE (1990) Longterm survival of sclerotia of Sclerotium cepivorum and Stromatinia gladioli. Plant Pathology 39:58-69.

Combrinck S, Regnier T, Kamatou GPP (2011) In vitro activity of eighteen essential oils and some major components against common postharvest fungal pathogens of fruit. Industrial Crops and Products 33:344-349 .

Coventry E, Allan EJ (2001) Microbiological and chemical analysis of neem (Azadirachta indica) extracts: New data on antimicrobial activity. Phytoparasitica 29:441-450.

Davis RM, Hao JJ, Romberg MK, Nunez JJ, Smith RF (2007) Efficacy of germination stimulants of sclerotia of Sclerotium cepivorum for management of white rot of garlic. Plant Disease 91:204-208.

Domingues RJ, Souza JDF, Töfoli JG, Matheus DR (2009) Ação in vitro de extratos vegetais sobre Colletotrichum acutatum, Alternaria solani e Sclerotium rolfsii. Arquivos do Instituto Biológico 76:643-649.

Esper RH, Gonçalez E, Marques MOM, Felicio RC, Felicio JD (2014) Potential of essential oils for protection of grains contaminated by aflatoxin produced by Aspergillus flavus. Frontiers in Microbiology 5 (Article 269):5p.

Ferreira FD, Mossini SAG, Ferreira FMD, Arrotéia CC, Costa CL, Nakamura CV, Machinski Júnior M (2013) The inhibitory effects of Curcuma longa L. essential oil and curcumin on Aspergillus flavus Link growth and morphology. The Scientific World Journal Article ID 343804:6p.
Fuga CAG, Lopes EA, Vieira BS (2012) Etiologia, epidemiologia e controle de doenças causadas por Sclerotium rolfsii e S. cepivorum. Revisão Anual de Patologia de Plantas 20:278-322.

Gomez KA, Gomez AA (1984) Statistical procedures for agricultural research. John Wiley, New York. 680p.

Martins CR, Lopes WA, Andrade JB (2013) Solubilidade das substâncias orgânicas. Química Nova 36:1248-1255.

Montes-Belmont R, Prados-Ligero AM (2006) Influence of plant extracts on Sclerotium cepivorum development. Plant Pathology Journal 5:373-377.

Ozcan MM, Chalchat JC (2008) Chemical composition and antifungal activity of rosemary (Rosmarinus officinalis L.) oil from Turkey. International Journal of Food Sciences and Nutrition 59:691-698.

Park I, Kim J, Lee S, Shin S (2007) Nematicidal activity of plant essential oils and components from ajowan (Trachyspermum ammi), allspice (Pimenta dioica) and litsea (Litsea cubeba) essential oils against pine wood nematode (Bursaphelenchus xylophilus). Journal of Nematology 39:275-279.

Parveen Z, Nawaz S, Siddique S, Shahzad K (2013) Composition and antimicrobial activity of the essential oil from leaves of Curcuma longa L. Kasur variety. Indian Journal of Pharmaceutical Sciences 75:117$-122$.

Pereira RB, Lucas GC, Perina FJ, Resende MLV, Alves E (2011) Potential of essential oils for the control of brown eye spot in coffee plants. Ciência e Agrotecnologia 35:115-123.

Pinto CMF, Maffia LA, Berger R, Casali VWD, Cardoso (2000) Production components and yield loss of garlic cultivars planted at different times in a field naturally infested with Sclerotium cepivorum. International Journal of Pest Management 46: 67-72.

Pinto CMF, Maffia LA, Casali VWD, Cardoso AA (1998) In vitro effect of plant leaf extracts on mycelial growth and sclerotial germination of Sclerotium cepivorum. Journal of Phytopathology 146:421-425.

Pinto JMA, Souza EA, Oliveira DF (2010) Use of plant extracts in the control of common bean anthracnose. Crop Protection 29:838-842.

R Development Core Team (2011) R: A language and environment for statistical computing. Vienna: R Foundation for Statistical Computing, 2011. Available in $<$ http://R-project.org>. 
Salgado APSP, Cardoso MG, Souza PE, Souza JP, Abreu CMP, Pinto JEBP (2003) Avaliação da atividade fungitóxica de óleos essenciais de folhas de Eucalyptus sobre Fusarium oxysporum, Botrytis cinerea e Bipolaris sorokiniana. Ciência e Agrotecnologia 27:249-254.

Sharma N, Tiwari R (2013) Biological effects of ginger (Zingiber officinale Roscoe) essential oil on Alternaria alternate (Fr.) Keissl. International Journal of Recent Scientific Research 4:827-831.

Simic A, Rancic A, Sokovic MD, Ristic M, GrujicJovanovic S, Vukojevic J, Marin MD (2008) Essential oil composition of Cymbopogon winterianus and Carum carvi and their antimicrobial activities. Pharmaceutical Biology 46:437-441.

Soylu EM, Kurt S, Soylu S (2010) In vitro and in vivo antifungal activities of the essential oils of various plants against tomato grey mould disease agent Botrytis cinerea. International Journal of Food Microbiology 143:183-189.

Stewart A, McLean KL (2007) Biological control of onion white rot. In: Chincholkar SB, Mukerji KG. (ed.) Biological control of plant diseases, The Haworth Press, cap.6, p.123-148.

Tabanca N, Demirci B, Husnu CBK, Mincsovics E, Khan SI, Jacob MR, Wedge DE (2007) Characterization of volatile constituents of Scaligeria tripartita and studies on the antifungal activity against phytopathogenic fungi. Journal of Chromatography B 850:221-229.
Tomazi MA, Costa AV, Rodrigues WN, Pinheiro PF, Parreira LA, Rinaldo D, Queiroz VT (2014) Composição química e atividade alelopática do óleo essencial de eucalipto. Bioscience Journal 30:475-483.

Triana AC, González DR (2009) Efecto del oleo Nim $50 \mathrm{CE}$ sobre el crecimiento y desarrolo in vitro de hongos fitopatógenos del arroz (Oryza sativa Lin.). Fitosanidad 13:271-276.

Vieira SS, Cardoso MG, Souza PE, Guimarães LGL, Andrade MA, Andrade J (2012) Composição química e atividade fungitóxica do óleo essencial de Ageratum conyzoides L. (mentrasto). Magistra 24:55-62.

Villalta ON, Wite D, Porter IJ, McLean KL, Stewart A, Hunt $J$ (2012) Integrated control of onion white rot on spring onions using diallyl disulphide, fungicides and biocontrols. Acta Horticulturae 944:63-71.

Vizzotto M, Pereira MC (2011) Amora-preta (Rubus sp.): Otimização do processo de extração para determinação de compostos fenólicos antioxidantes. Revista Brasileira de Fruticultura 33:1209-1214.

Zewide T, Fininsa C, Sakhuja PK (2007) Management of white rot (Sclerotium cepivorum) of garlic using fungicides in Ethiopia. Crop Protection 26:856-866. 